\title{
PERAN PSIKOLOGI PENDIDIKAN DALAM UPAYA MENINGKATKAN MUTU PENDIDIKAN
}

\author{
Rahimah \\ 2010128220022@mhs.ulm.ac.id \\ Program Studi Pendidikan IPS \\ Fakultas Keguruan dan Ilmu Pendidikan \\ Universitas Lambung Mangkurat \\ Banjarmasin
}

\begin{abstract}
Abstrak
Psikologi pendidikan ini merupakan suatu ilmu yang menyelidik dan juga mempelajari secara kompeherensif dan juga kritis tentang perilaku manusia itu sendiri. Pada psikologi pendidikan ini merupakan sebuah aktivitas pada seseorang yang berhubungan dengan pendidikan atas hasil interaksinya yang penting pada masalah yang mengganggu atau pendukung pada proses pembelajaran. Oleh sebab itu, harusnya seorang guru memiliki pengetahuan yang memadai terhadap psikologi pendidikan ini agar pada pembelajaran terarah dan juga efektif bagi peserta didiknya.
\end{abstract}

\section{Kata kunci: pembelajaran, psikologi, pendidikan}

\section{PENDAHULUAN}

Pendidikan itu sendiri memiliki tujuan agar terjadinya perubahan pada seseorang ke arah yang positif. Karena masalah dari pendidikan akan menjadi masalah yang dimana menyangkut pada kehidupan seseorang tersebut. Pendidikan ini aktivitas yang menyangkut akan hal dalam penentuan sebuah kehidupan manusia yang baik serta kebudayaannya. Dengan adanya pendidikan ini maka kan membawa perubahan yang baik untuk kedepannya. Salah satu yang menjadi faktor berhasilnya pendidikan melalui pembelajaran adalah guru tersebut. Karena guru inilah yang menjadi orang yang dimana memberikan sebuah pengetahuan dan lainnya terhadap peserta didik pada proses belajar dan pembelajaran. Pada faktor psikologis itu sendiri guru harus mampu memberikan kendali dalam mengatur proses pembelajaran.

Kegunaan dari psikologi pendidikan agar membantu dalam hal memahami karakter peserta didik. Jika guru mampu dalam memahami karakter dari peserta didik tersebut maka 
pembelajaran akan terlaksana secara maksimal dan optimal pada proses pembelajaran. Sehingga perlunya guru dalam memiliki pengetahuan akan hal yang berkenaan dengan psikologi pendidikan sehingga dapat digunakan pada pembentukan dari karakter peserta didik tersebut. Pendidikan akan berjalan efektif apabila pendidikan tersebut memenuhi dari kebutuhan pada psikologi seorang anak tersebut.

\section{METODE}

Dalam penulisan artikel ini menggunakan suatu metode yang materinya didapat dari jurnal dan juga buku yang relevan. Materi yang sudah di dapat dikumpulkan dan juga dipilih kerelevanannya dan kebenarannya. Setelah itu, maka dibuatlah serangkaian penulisan yang dibuat secara fakta dalam sebuah penulisan artikel ini.

\section{PEMBAHASAN}

Psikologi ini berasal kata yaitu "psyce" yang artinya jiwa dan "logos" yang artinya ilmu. Jadi psikologi ini di artikan sebagai ilmu yang berkenaan tentang kejiwaan. Menurut ahli yang bernama Wundt psikologi ini merupakan ilmu yang menyelidik sebuah pengalaman yang ditimbulkan manusia seperti pikiran, perasaan, motivasi dan juga pikiran yang tidak berasal dari diri luar manusia. Dengan demikian, bahwa dapat di tarik kesimpulan psikologi pendidikan ini ialah sebuah ilmu yang menyelidik dan juga mempelajari secara kompeherensif dan juga kritis tentang perilaku manusia itu sendiri.

\section{Kajian mengenai psikologi pendidikan}

Ada 4 kajian yang berkenaan dengan psikologi itu, yaitu:

a. Kajian tentang perilaku. Dengan adanya kajian ini maka dapat mempelajari seseorang dari segi tingkah lakunya bukan dari sistem sarafnya ataupun otaknya. Sebutan lain dari kajian ini adalah behaviorisme.

b. Kajian tentang kognitif. Kajian ini merupakan dari reaksinya behaviorisme. Perspektif dari kognitif ini reaksi yang berkenaan dengan kecilnya suatu pandangan akan hal stimulus-respon.

c. Kajian psikoanalitik. Kajian ini memandang bahwa tindakan itu mempunyai sebuah sebab tetapi sebab itu lebih ke arah suatu motif bawah sadar ketimbang dengan penalaran secara rasional yang digerakkan oleh tingkah laku. pada kajian melihat suatu kajian yang baru sebagai pandangan akan masalah pada jiwa seseorang. 
d. Kajian tentang biologis. Pada kajian ini menimbulkan berkembangnya pada penelitian memori dan belajar. Hal yang berkenaan ini agar mempelajari manusia dan spesies lainnya yang berhubungan tentang tingkah laku terhadap sebuah peristiwa.

\section{Ruang lingkupnya psikologi pendidikan}

Ada beberapa ruang lingkup dari psikologi pendidikan ini, yaitu:

a. Perkembangan dan pertumbuhan individu

Pada perkembangan lebih mengarah kepada perubahan akan kemampuan yang dimiliki atas kualitas dari kemampuan, ciri dan sifat yang baru. Umumnya konsep perkembangan ini perubahan akan kualitas dari kematangan berpikir seseorang tersebut. Sedangkan pada pertumbuhan adalah perubahan yang biasanya terjadi tentang perubahan pada fisik. Perkembangan dan pertumbuhan merupakan kedua hal yang saling memiliki keterkaitan dan tidak saling terpisahkan. Kedua hal ini berhubungan sekali dengan pendidikan karena pada pendidikan ini tentunya melewati akan hal perkembangan dan pertumbuhan pada peserta didik.

b. Kejiwaan seorang anak

Pada masa kanak-kanak adalah masa awal yang menjadi perkembangan dan pertumbuhan seseorang. Psikologi pada masa kanak-kanak akan memberikan pemaknaan yang dalam terhadap terbentuknya dari kepribadian seseorang. Perkembangan pada psikologi anak melewati beberapa tahapan, yaitu tahap sensorik-motorik adalah suatu tahapan yang berulang-ulang agar tercapainya tujuan. Tahap pra-operasional adalah tahap pada individu mulai bisa membedakan benda. Tahap konkrit operasional adalah tahap mulai timbul adanya timbal balik. Dan selanjutnya adalah tahap formal-operasional yang dimana pada tahap ini individu mulai berpikir abstrak. Orang lain perlu dalam perkembangan anak agar si anak tidak mengalami gangguan pada jiwanya. Lingkungan keluarga merupakan lingkungan awal yang atas pendidikan terhadap seorang anak dalam mengalami perkembangan dan pertumbuhan.

c. Kecerdasan 
Setiap orang memiliki kecerdasannya masing-masing. Tidak bisa disamakan setiap orang memiliki kecerdasan yang sama. Dalam psikologi pendidikan sendiri di anggap kecerdasan ini merupakan salah satu dari ruang lingkup dari psikologi pendidikan. Dengan meningkatnya kecerdasan anak maka akan penting dalam meningkatkan keberhasilan bagi anak tersebut. adapun faktor yang menjadi meningkatnya prestasi pada anak adalah dari segi sikap, motivasi, kepribadian dan ketekunan dari anak tersebut. umumnya kecerdasan ini karena pola pikir yang baik pada suatu aktivitas. Kemampuan intelektual yang dimiliki yang dimana telah tercapai karena proses pembelajaran dan pengajaran yang akan di jalankan dalam kehidupan. Pada psikologi pendidikan sendiri juga mempelajari akan hal dalam peningkatan keefektivitasan belajar dan pengaruhnya berkenaan perkembangan jiwa seseorang.

d. Motivasi

Motivasi ini muncul karena adanya dorongan yang dalam seseorang untuk melakukan sebuah pembelajaran agar tercapainya akan suatu tujuan dari perencanaan. Motivasi ini akan berhasil dengan kuat apabila motif yang diberikan juga kuat. Ada beberapa motif pada motivasi ini. Motifnya bisa berupa kebutuhan, kehendak, dorongan dari gerakan hati yang kuat pada diri seseorang tersebut. Pada psikologi sendiri dorongan ini disebut juga dengan motivasi. Motivasi ini dapat berawal dari dalam diri individu itu sendiri ataupun juga dari luar individu tersebut. Tentunya dalam upaya melakukan proses pembelajaran, motivasi ini sangat diperlukan sebagai pendorong bagi anak tersebut dalam melakukan pembelajaran.

\section{Pemahaman tentang peranan dari psikologi pendidikan}

Pada umumnya suatu masalah pada bidang pendidikan ini sangat membutuhkan seseorang yang ahli di bidang kesehatan mental. Permasalahan lainnya juga pada pendidikan ini adalah biasanya peserta didik mengalami kesulitan dalam mengikuti pembelajaran. Hal tersebut terlepas pada permasalahan pendidikan dari segi kurangnya sarana prasarana yang ada di sekolah dan lainnya. Misalnya saja peserta didik tersebut dalam hal kegiatan dia mengalami keterlambatan dalam menerima pendidikan. Yang dimana dengan hal demikian juga membuat mutu pendidikan tersebut tidak berjalan 
karena dari peserta didiknya juga mengalami keterlambatan dalam menerima pengetahuan. Padahal dengan peserta didik tersebut paham dan mengerti akan dari pengetahuan tersebut maka akan membuat peserta didik dapat menjadi warga masyarakat yang baik atas hasil dari proses pendidikannya. Sehingga perlunya seorang guru tersebut untuk menemukan permasalahan yang di alami peserta didiknya dan juga melakukan pemecahan masalah akan hal demikian tersebut.

Selain itu juga, permasalahan pendidikan sering terjadi karena kurang berkualitasnya guru dalam melakukan pembelajaran. Misalnya saja permasalahan guru yang tidak bisa memahami karakter dari peserta didik tersebut, sehingga dalam melakukan proses pembelajaran guru tersebut salah dalam memberikan metode dan model pembelajaran terhadap peserta didiknya. Seharusnya guru tersebut harus bisa memahami dari karakter peserta didik tersebut agar dapat menggunakan metode dan model pembelajaran yang tepat untuk melakukan proses pembelajaran yang tepat pula. Dengan demikian, maka akan terlaksananya pendidikan yang memadai dan sesuai dengan tujuan dari pendidikan tersebut dan membuat pembelajaran akan bermakna bagi peserta didiknya.

Pendidikan dalam hal pembelajaran kepada peserta didik harus relevan sesuai dengan kebutuhan peserta didik. Guru merupakan seseorang yang menjadi rekanan belajar adalah hal berkomunikasi, berinteraksi dan lain halnya pada proses pembelajaran yang dilakukan peserta didik. Penguasaan dalam hal kejiwaan peserta didik akan membuat rangsangan semangat bagi peserta didik. Seorang guru tidak hanya dituntut untuk memberikan pembelajaran dalam hal pengetahuan kepada peserta didik, namun juga seorang guru harus bisa memahami tentang kepribadian karakter yang dimiliki peserta didik.

Para pendidik melihat bahwa psikologi ini sumber akan pengetahuan terhadap manusia dalam praktek dunia pendidikan. Dalam hal ini psikologi pendidikan guru akan mampu dalam mengelola sebuah metode dam model pembelajaran yang dimana akan di terapkan pada proses pembelajaran dan akan berjalan lancar jika seorang guru tersebut mampu memahami dari kepribadian peserta didiknya. Jadi dalam dunia pendidikan psikologi ini berperan agar tidak hanya berfokus pada meningkatnya mutu pendidikan 
tersebut dan juga mampu dalam meningkatkan mutu belajar peserta didik yang berhubungan dengan berkembangnya psikis anak dan lainnya.

Peranan akan hal dari psikologi pendidikan ini, yaitu:

a) Emosi

Emosi merupakan keadaan jiwa seseorang yang dapat mempengaruhi pada proses belajar. Jika seorang guru mampu memahami hal demikian agar seorang guru mampu dalam memberlakukan pembelajaran yang bijaksana.

b) Pembentukan karakter dan prestasi

Kepribadian yang ada pada diri seorang guru akan mempengaruhi pada pembelajaran. Dengan psikologi pendidikan ini maka akan membantu guru dalam memahami tentang dirinya dalam melakukan pembelajaran sehingga melakukan pembelajaran dengan baik dan pada saat proses pembelajaran berjalan dengan lancar maka akan meningkat pula terhadap prestasi peserta didik.

c) Membangkitkan motivasi

Tujuan dari psikologi pendidikan ini adalah agar bangkitnya motivasi belajar bagi peserta didik. Psikologi pendidikan ini akan menjadi cara yang dapat dijadikan sebagai awal untuk berpikir, bertindak dalam pengelolaan pembelajaran. Dengan guru memahami dari kepribadian peserta didik ini maka akan terciptanya suasana pembelajaran yang efektif dan efisien dalam membangkitkan motivasi belajar peserta didik sebagai pembangun peserta didik ke depannya.

\section{SIMPULAN}

Pendidik seharusnya mampu dalam menjalankan tugasnya sebagai tenaga pendidik. Karena pada proses pengajaran ataupun pembelajaran tidak hanya sebuah proses dalam menyampaikan sebuah pengetahuan terhadap peserta didiknya, namun juga sebagai seseorang yang menjadi salah satu pembentukan peserta didik selain keluarganya. Permasalahan yang dihadapi pada pendidikan ini tidak hanya dari segi kurangnya sarana dan prasarana yang ada di sekolah namun juga berkenaan dengan proses belajar dari peserta didiknya dan pemahaman guru terhadap memahami karakter dari peserta didik tersebit. Selain itu juga, guru harus mampu pemahaman dalam pengaplikasian dari pembelajaran tersebut lebih bermakna yang bisa diterapkan untuk kehidupannya. Dengan demikian, guru 
harus mampu dalam memahami kejiwaan anak agar kemampuan yang dimiliki anak berkembang lewat pembelajaran yang dilakukan secara optimal. Dengan guru memiliki pemahaman akan hal demikian maka akan terlaksananya pembelajaran yang optimal dan memadai dalam hal psikologi anak.

\section{REFERENSI}

Abbas, E. W (2019). Membangun Karakter Bangsa Melalui Pendidikan: Melanjutkan Seminar Internasional Pendidikan Karakter.

Abbas, E. W. (2013). Mewacanakan Pendidikan IPS. Mewacanakan Pendidikan IPS.

Desmita. (2005). Psikologi Perkembangan. Bandung: Remaja Rosda Karya.

Mutiani, M., Sapriya, S., Handy, M. R. N., Abbas, E. W., \& Jumriani, J. (2021). Pembinaan Etika Peserta Didik Melalui Pembelajaran Tematik-Integratif Di Sekolah Dasar. Edukatif: Jurnal Ilmu Pendidikan, 3(3), 704-709.

Putra, M. H., Mutiani, M., Jumriani, J., Ramadhan, S., \& Rahmatina, R. (2020). Utilization Learning Management System (LMS) of Ruang Guru for Education Teachers in Banjarmasin. The Kalimantan Social Studies Journal, 2(1), 31-38.

Putro, H. N. (2013). Pengembangan Pembelajaran IPS dalam Kurikulum 2013. Mewacanakan Pendidikan IPS, 39.

Rusmaniah, R., Mardiani, F., Handy, M. R. N., Putra, M. A. H., \& Jumriani, J. (2021). Social Services Based on Institutional for Youth Discontinued School. The Innovation of Social Studies Journal, 2(2), 151-158.

Sakerebau, J. (2018). Memahami Peran Psikologi Pendidikan Bagi Pembelajaran. BIA: Jurnal Teologi dan Pendidikan Kristen Kontekstual, 1(1), 96-111.

Saputra, A. MASALAH BELAJAR DALAM PERSPEKTIF PSIKOLOGI PENDIDIKAN.

Slameto. (2003). Belajar dan Fktor-Faktor Yang Mempengaruhinya. Jakarta: Rineka Cipta.

Subiyakto, B., \& Abbas, E. W. (2020). Strategi Pembelajaran IPS: Konsep dan Aplikasi.

Suryabrata, S. (2004). Psikologi Pendidikan. Jakarta: Raja Grafindo Persada. 
Uyun, M. (2020). Peran Psikologi dalam Bidang Pendidikan, Pemerintahan dan Industri. Psympathic: Jurnal Ilmiah Psikologi, 7(1), 61-78.

Warmansyah Abbas, E. R. S. I. S. (2020). Menulis di Era Covid-19: Memanage Trauma Psikologis Menghindari Psikosomatis. Menulis di Era Covid-19: Memanage Trauma Psikologis Menghindari Psikosomatis. 